\title{
An Overview of the Molecular Genetics of Plant Resistance to the Verticillium Wilt Pathogen Verticillium dahliae
}

\author{
Ranran Song, Junpeng Li, Chenjian Xie *, Wei Jian and Xingyong Yang * \\ Chongqing Engineering Research Center of Specialty Crop Resources and The College of Life Science, \\ Chongqing Normal University, Chongqing 401331, China; s13628213851@163.com (R.S.); \\ ljpW0501@163.com (J.L.); jianwei7956@163.com (W.J.) \\ * Correspondence: xcj614@163.com (C.X.); yangxy94@swu.edu.cn (X.Y.); Tel.: +86-23-6591-0315 (C.X. \& X.Y.)
}

Received: 13 December 2019; Accepted: 28 January 2020; Published: 7 February 2020

\begin{abstract}
Verticillium dahliae is a soil-borne hemibiotrophic fungus that can lead to plant vascular disease and significant economic loss worldwide. Its hosts include over 400 dicotyledon plant species, such as annual herbs, perennials, and woody plants. The average yield loss of cotton crop caused by Verticillium wilt is approximately $10-35 \%$. As the control of this disease is an urgent task for many countries, further understanding of the interaction between plants and $V$. dahliae is essential. Fungi can promote or inhibit plant growth, which is important; however, the most important relationship between plants and fungi is the host-pathogen relationship. Plants can become resistant to $V$. dahliae through diverse mechanisms such as cell wall modifications, extracellular enzymes, pattern recognition receptors, transcription factors, and salicylic acid (SA)/jasmonic acid (JA)/ethylene (ET)-related signal transduction pathways. Over the last decade, several studies on the physiological and molecular mechanisms of plant resistance to $V$. dahliae have been undertaken. In this review, many resistance-related genes are summarised to provide a theoretical basis for better understanding of the molecular genetic mechanisms of plant resistance to $V$. dahliae. Moreover, it is intended to serve as a resource for research focused on the development of genetic resistance mechanisms to combat Verticillium wilt.
\end{abstract}

Keywords: plant resistance; resistance-related genes; vascular plant diseases; Verticillium dahliae

\section{Introduction}

The soil-borne hemibiotrophic phytopathogenic fungus Verticillium dahliae can cause refractory vascular Verticillium wilt in a wide range of crops worldwide due to its highly aggressive pathogenicity and production of melanised dormant structures called microsclerotia, which can survive for several years in the soil [1]. It produces cell wall-degrading enzymes and phytotoxins, which cause signs of the disease. The fungus infects more than 200 dicotyledon plant species, such as annual herbs, perennials, and woody plants. The average yield loss of cotton crop caused by Verticillium wilt is approximately $10-35 \%$ in many countries. It generally causes plant dysplasia, leaf wilt, and yellowing and browning of vascular bundles, eventually leading to early death in some plants. At present, there are no fungicides available to control the infected plants [2], and thus Verticillium wilt results in extensive economic losses [3].

$V$. dahliae can infect a variety of dicotyledonous species including cotton, tobacco, tomatoes, Arabidopsis, and others. It usually invades and colonises the roots of plants, and then spreads throughout the plant [4]. $V$. dahliae begins to infect the roots of the plant through the soil, and hyphae penetrate the surface of the plant roots to colonise the vascular bundles, leading to plant death $[5,6]$. 
The main mechanism of its pathogenesis is xylem vessel blockage and toxin production. When the fungus invades the plant body, the mycelium blocks the xylem vessel, affecting the transport of water and nutrients in the plant [1,7]. However, transpiration and respiration of the aerial part are strong, causing water imbalance in the plant and signs such as leaf wilting and yellowing, which eventually leads to plant death [8]. However, catheter blockage is not the primary cause of plant wilting [7,9]. In the toxin theory, histological evidence indicates that leaf necrosis is caused by the action of mycotoxins [10]. The toxin produced by $V$. dahliae is an acidic protein-lipopolysaccharide complex [11]. It can seriously damage the metabolism of the plant body, fix carbon dioxide, decompose $\mathrm{H}_{3} \mathrm{PO}_{4}$, and eventually lead to plant death [12]. Current research indicates that toxin production is the main cause of plant wilting $[2,13]$.

Plants have evolved numerous defence mechanisms to protect themselves from invading pathogens [14], and plant extracellular enzymes and the cell wall are the first defence barriers. Subsequently, plants induce pathogen-associated molecular pattern (PAMP)-triggered immunity by recognizing pathogens using cell-surface pattern recognition receptors (PRRs). In turn, pathogens have evolved mechanisms such as effectors to overcome these PAMP-induced defence mechanisms. The effector is recognised by plants to activate effector-triggered immunity (Figure 1). The plant immune defences have been described as a 'zigzag' model, in which many genes are involved in this 'zigzag' procedure [15].

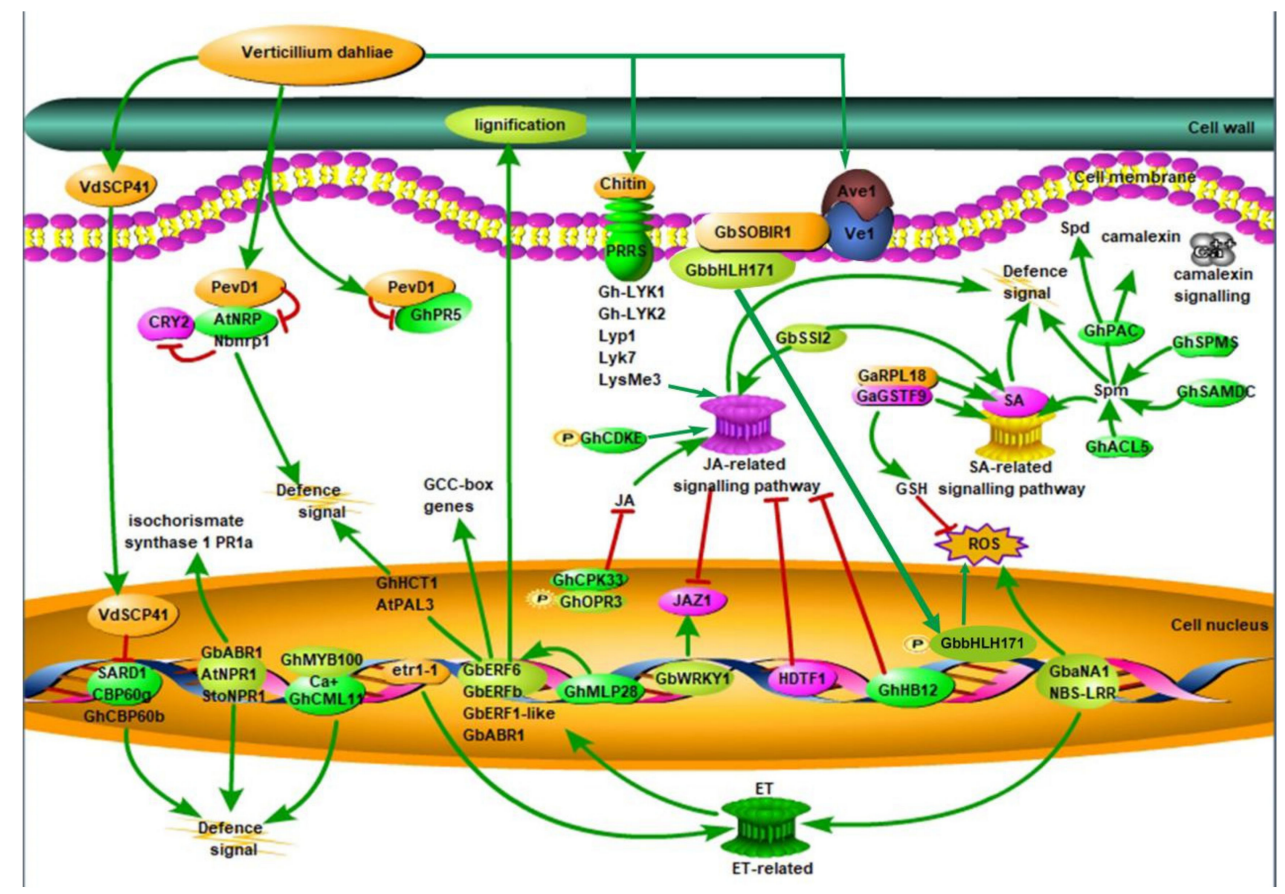

Figure 1. Regulation of intracellular signalling-related genes and signal transduction-related genes in response to Verticillium dahliae in plants. Plants have developed a sophisticated immune system to defend against $V$. dahliae. Plant cells immediately trigger signal transduction, leading to a rapid defence response including large-scale transcription reprogramming, while they recognise microbial-related molecular patterns or internal effectors from V. dahliae. $P$, phosphorylation; CRY2, cryptochrome 2; ET, ethylene; GCC-box, ethylene-responsive element binding factor associated amphiphilic repression domain; GSH, phi-class glutathione; HDTF1: homeodomain transcription factor gene 1; JA, jasmonic acid; JAZ1, Jasmonate Zim-domain1; NBS-LRR, nucleotide-binding site leucine-rich repeat; PevD1, an elicitor from $V$. dahliae; SARD1, the Arabidopsis master immune regulator; SA: salicylic acid; Spd, spermidine; Spm, spermine; ROS, reactive oxygen species; SA, salicylic acid; VdSCP41, a secretory protein from $V$. dahliae [7,16-22]. Red lines represent negative regulation and green lines represent positive regulation. 
Functional analysis of the key genes involved in growth and pathogenicity is the molecular genetic basis of revealing plant resistance to $V$. dahliae. Currently, several studies focusing on plant resistance to $V$. dahliae have been reported. In this review, some key findings and resistance-related genes are summarised to provide a theoretical basis to further understand the molecular genetic mechanisms of plant resistance to $V$. dahliae.

\section{Defence-Related Proteins}

In plants, defence-related proteins play a significant role in plant resistance to fungal pathogens. Polygalacturonase, which digests pectin in plant cell walls, contributes to fungal pathogenicity and plays a considerable role in the pathogenicity of $V$. dahliae [23]. A class of plant defence proteins, polygalacturonase-inhibiting proteins (PGIPs), can specifically inhibit endo-polygalacturonases. Further, the overexpression of CkPGIP1 from Cynanchum komarovii and GhPGIP1 from Gossypium hirsutum in cotton can improve cotton resistance to $V$. dahliae, which is associated with the upregulated expression of pathogenesis-related proteins (PRs), enhanced disease susceptibility 1 (EDS1), phytoalexin-deficient 4 (PAD4), and isochorismate synthase 1 (ICS1) genes that enhance xylem lignification $[24,25]$.

$\mathrm{NaD1}$, a plant defensin from Nicotiana alata with strong antifungal activity against many filamentous fungi, is associated with significant resistance to $V$. dahliae after transgenic expression in cotton plants [26]. GbNRX1 gene codes an apoplastic thioredoxin protein from Verticillium wilt-resistant island cotton (G. hirsutum cv Hai 7124), which is associated with an increase in abundance in response to $V$. dahliae infection. The observed increase in apoplastic reactive oxygen species (ROS) accumulation and reduced $V$. dahliae resistance in GbNRX1-silenced plants suggest that GbNRX1 can scavenge apoplastic ROS and is pivotal for the apoplastic immune response [27]. Hydroxyproline-rich proteins (HyPRPs) comprise a plant cell wall glycoprotein subfamily enriched in proline. The GbHyPRP1 protein from Gossypium barbadense contains proline-rich repetitive and Pollen Ole e I domains and negatively regulates the resistance of cotton plants to $V$. dahliae. GbHyPRP1 silencing was shown to markedly enhance cotton plant resistance to $V$. dahliae via cell wall thickening and ROS accumulation [28].

Non-expressor of pathogenesis-related protein 1 (NPR1) is a key regulator of systemic acquired resistance (SAR) in plants. When plants lack functional NPR1, their ability to express the PR gene is impaired and they show a near-total lack of an SAR response to pathogen infection [29]. Constitutive expression of the Arabidopsis NPR1 (AtNPR1) gene in cotton significantly increases the resistance of transgenic plants to non-defoliating $V$. dahliae [30]. StoNPR1, a Solanum torvum NPR1 gene, was previously expressed in $V$. dahliae-sensitive potato, which increased the resistance of transgenic plants to $V$. dahliae. Further, ICS1 and PR1a expression was also evidently enhanced in the StoNPR1 overexpression lines and was significantly induced by $V$. dahliae infection [31]. GhMLP28, a defence-related major latex protein (MLP) from G. hirsutum, is induced by V. dahliae, jasmonic acid (JA), salicylic acid (SA), and ethylene (ET). GhMLP28 silencing enhances the susceptibility of cotton plants to V. dahliae infection, whereas GhMLP28 ectopic overexpression in tobacco increases disease resistance. A further assay demonstrated that GhMLP28 activates the transcription factor activity of ET response factor 6 (GhERF6), which augmented the expression of some GCC-box (AGCCGCC element) genes, contributing to defence against $V$. dahliae [32].

Sulphur plays a considerable role in tomato disease resistance against $V$. dahliae. The expression of genes related to sulphur uptake and assimilation, sulphur-containing defence compounds, and high-affinity sulphate transporter genes are increased in $V$. dahliae-infected tomatoes during companion cropping [33]. The haumatin-like protein (TLP) gene is related to plant biotic and abiotic stress regulation. Transgenic plants with higher expression of the cotton TLP gene (GbTLP1) show enhanced resistance to different stress factors including $V$. dahliae infection [34]. A synthetic non-cyclic 0200-defensin derivative, BTD-S, shows robust antimicrobial activity to $V$. dahliae in vitro [35]. Further, the expression of BTD-S in Arabidopsis thaliana increases resistance to V. dahliae [36]. 
StoCYP77A2 is a wild eggplant cytochrome P450 gene and is induced by $V$. dahliae. Constitutive expression of StoCYP77A2 in tobacco enhances plant resistance to $V$. dahliae infection. Protein extraction from StoCYP77A2-transgenic tobacco indicated strong antifungal activity, which implies that StoCYP77A2 should participate in the synthesis of some antifungal compounds [37]. GhDIR1 encodes a putative dirigent protein and its overexpression leads to increases in lignin content in transgenic cotton plants, which display enhanced tolerance to V. dahliae infection [38]. GhUMC1, an umecyanin-like gene in cotton, is involved in the resistance of cotton plants to $V$. dahliae through regulation of the JA signalling pathway and lignin metabolism [39].

\section{Enzymes}

In plants, extracellular enzymes are often the first line of defence against fungal pathogens. Increasing evidence shows that chitinase is a key hydrolytic enzyme, which degrades the fungal cell wall [40], and its expression can be initiated in response to biotic and abiotic stress [41]. Chi28 belongs to the class IV chitinase subfamily, and Chi28 silencing significantly impairs cotton plant resistance to $V$. dahliae. VdSSEP1, a secretory serine protease, was shown to hydrolyse Chi28; however, cotton apoplastic protein CRR1 protects Chi28 from VdSSEP1-induced cleavage [42].

Pectins as the main element of the primary plant cell wall play a key role in defence mechanisms against plant pathogens. Pectin methylesterases (PMEs) catalyse dimethyl esterification of the homogalacturonan domains of pectin in the plant cell wall. GhPMEI3 silencing in cotton leads to enhanced susceptibility to V. dahliae. Moreover, GhPMEI3 and GhPMEs might participate in protein-protein interactions and are important for plant evolution to resist fungal pathogens [43].

Lignification in the plant cell wall is a plant innate immune defence response and the lignification of lignin in resistant cotton stems contributes to the resistance of cotton to disease [44]. GhLAC15, a laccase gene, was demonstrated to be strongly induced by pathogens. Moreover, its overexpression increases Verticillium wilt resistance via increased defence-induced lignification and arabinose and xylose accumulation in the upland cotton cell wall [45].

The expression of GbSBT1 in G. babardense, which encodes a subtilase that is mainly localised to the cell membrane, is induced by $V$. dahliae, JA, and ET, as it translocates to the cytoplasm following JA and ET treatment. GbSBT1 gene silencing reduces the tolerance of Pima-90 (resistant genotype) to $V$. dahliae infection. Moreover, the overexpression of GbSBT1 activates the expression of defence-related genes and increases Arabidopsis resistance to Fusarium oxysporum and V. dahliae [46].

Enoyl-CoA reductase (ECR) plays a crucial role in very-long-chain fatty acid formation. $G h E C R$-silenced cotton plants are susceptible to $V$. dahliae infection, indicating that the GhECR gene is related to cotton resistance to different $V$. dahliae strains [47]. Cotton GbANS contributes to anthocyanin biosynthesis, and GbANS silencing significantly reduces anthocyanin production and cotton plant resistance to V. dahliae [48]. A U-box E3 ubiquitin ligase, GhPUB17, which can interact with and is inhibited by the antifungal protein $\mathrm{GhCyP3}$, negatively regulates cotton resistance to Verticillium wilt pathogen [49]. The production of gossypol is sufficient to influence the resistance of cotton plants to $V$. dahliae. As such, silencing GbCAD1, encoding a key enzyme involved in gossypol biosynthesis, compromises cotton plant resistance to $V$. dahliae [50].

\section{Receptor-Like Proteins}

Lysin motif (LysM)-containing proteins are important PRRs in plants, which function in chitin recognition and the activation of defence responses against fungal pathogen attacks [51-53]. GhLYK1 and GhLYK2, two LysM-containing proteins, are induced after $V$. dahliae infection. However, GhLYK1 and GhLYK2 silencing compromises cotton plant resistance to $V$. dahliae. GhLYK2, but not GhLYK1, can induce ROS bursts in plants. Therefore, GhLYK2 and GhLYK1 might be distinctively dedicated to cotton defence [54]. In addition, in cotton, three important PRRs (Lyp1, Lyk7, and LysMe3) play an important role in activating downstream defence processes and inducing the defence response to $V$. 
dahliae via the recognition of chitin signals. The three PRR proteins are induced in response to $V$. dahliae, and their silencing greatly impairs SA, JA, and ROS generation, as well as resistance to $V$. dahliae [53].

In tomato (Solanum lycopersicum), Ve encodes receptor-like proteins containing extracellular leucine-rich repeats, and the Ve R-gene locus contributes to Verticillium resistance [25]. Ve1 is involved in the race-specific resistance to Verticillium wilt pathogen infection [55]. The Ve locus includes two closely-linked inverted genes, $V e 1$ and $V e 2$, encoding the extracellular leucine-rich repeat receptor-like protein (eLRR-RLP) and cell surface receptors [16]. Furthermore, it was shown that Ve genes encode a class of cell-surface glycoproteins with leucine zipper and receptor-mediated endocytosis-like signals [56]. Antagonistic relationships exist between Ve1 and Ve2 proteins, in which Ve1 modulates the induction of defence/stress proteins by Ve2 [25]. However, Ve1 transgene introduction does not alter the endogenous Ve2 expression [57].

Ve1 mediates plant resistance by monitoring the presence of the Ave1 effector in $V$. dahliae [58]. Some results suggested that $\mathrm{H}_{2} \mathrm{O}_{2}$, peroxidase, lignins, phenylalanine-ammonia lyase $(P A L)$ gene expression, and JA are required for Ve1-mediated resistance to V. dahliae [59,60]. Ve1-transgenic Arabidopsis is only resistant to race 1, but not to race 2, strains of $V$. dahliae, V. albo-atrum, and $V$. longisporum. Importantly, the critical elements for resistance signalling are conserved, and the signalling components ACIF, MEK2, SERK3/BAK1, and SERK1 play a role in Ve1-positive regulation [61]. The defence signalling cascade downstream of Ve1 is required by ACIF, EDS1, NRC1, NDR1, MEK2, and SERK3/BAK1. Ve1-mediated plant defence requires the basal defence signalling elements EDS1, NRC1, and NDR1 [61,62]. The constitutive expression of tomato Ve1 in Arabidopsis, cotton, and tobacco plants results in increased resistance to Verticillium wilt [63]. As a consequence of Ve1/Ave1-induced immune signalling, the immune receptor Ve1 recognises the $V$. dahliae effector protein Ave1 and then triggers a hypersensitive response in tobacco and tomato [64], but it is not entirely required for Verticillium resistance [65].

Phylogenetic analysis also indicates that Ve1 homologues are extensively scattered in land plants, and that Ve1 homologues in hop (Humulus lupulus), potato (S. tuberosum), tobacco (Nicotiana glutinosa), and wild eggplant (S. torvum) have been cloned and characterised [66]. Gbve1, a tomato Ve homolog, was cloned from an island cotton cultivar with resistance to Verticillium wilt and it can be induced by $V$. dahliae infection via SA, JA, and ET. Gbve1 silencing in resistant cotton decreases the resistance to $V$. dahliae. Conversely, the overexpression of Gbve1 in Arabidopsis and upland cotton plants enhances resistance to $V$. dahliae [67].

$V e$ homologous genes, Gbvdr3 and Gbvdr6, encode plasma membrane receptor-like protein in the Verticillium wilt-resistant cotton cultivar G. barbadense Hai7124 [68,69]. Silencing and overexpression experiments suggested their involvement in cotton resistance against $V$. dahliae and that they can enhance transgenic cotton or Arabidopsis resistance to $V$. dahliae. Their expression is activated by SA, methyl jasmonate, abscisic acid, and ET, and is induced by $V$. dahliae. In transgenic Arabidopsis, the overexpression of Gbvdr3 and Gbvdr6 enhances the expression of JA/ET signalling pathway-related genes ethylene-responsive factor 1 (ERF1), PR3, and PDF 1.2; SA-related genes PR1 and PR2; the ET-regulated gene GST2; and ROS and callose accumulation in the early stage after $V$. dahliae infection [68-70].

A $V e 1$ homologous gene, $V v V e$, was identified in Vitis vinifera, and its overexpression in tobacco significantly increased resistance to $V$. dahliae and upregulated defence-related gene expression, including the SA-regulated pathogenesis-related protein gene (PR1), ET- and JA-regulated genes (ERF1), and lipoxygenase (LOX), and enhanced the accumulation of ROS, callose, and PAL [71]. StoVe1 is a Ve1 homolog from S. torvum, and StoVe1-overexpressing potato lines show increased resistance to V. dahliae [72]. StVe, a potential Verticillium wilt disease resistance gene, from S. torvum and SlVe1 from S. lycopersicoides are homologous to Ve1 and Ve2, respectively, and StVe and SlVe1 encode cell surface-like receptor proteins $[73,74]$.

Micro-RNAs (miRNAs) are indispensable regulators of plant responses to biotic and abiotic stresses [75]. RNA silencing has an important role in plant defence against fungal pathogens and exerts specific defence functions against $V$. dahliae [76]. Upland cotton KV-1 displays multi-level 
resistance against Verticillium wilt, and some novel small RNAs have been identified after infection by V. dahliae strains with different virulence, V991 and D07038 [77]. Variants 3444a-5p and miR5562 showed the highest expression level in virulent conditions, whereas miR1423a-5p showed low-level expression [78]. Members of the potato miR482 superfamily and their variants were shown to target a class of disease-resistance proteins with nucleotide-binding sites and leucine-rich repeat (LRR) motifs, and miR482e-overexpressing transgenic potato plants show hypersensitivity to $V$. dahliae infection [79]. GhlncNAT-ANX2 and GhlncNAT-RLP7 are two species-conserved long noncoding RNAs, and their silencing in cotton significantly increases resistance to $V$. dahliae, which is possibly related to the upregulated expression of lipoxygenase 1 and lipoxygenase 2 [80]. Expression of GbRLK, a receptor-like kinase gene from the disease-resistant cotton G. barbadense Hai7124, is induced by $V$. dahliae. Moreover, transgenic cotton and the overexpression of GbRLK in Arabidopsis plants result in resistance against V. dahliae infection [17].

\section{Transcription Factors}

The MYB family of proteins is both large and diverse, with many members functioning as transcription factors. Increasing evidence shows that plant MYB transcription factors partake in defence against pathogen infection. Infection by $V$. dahliae stimulates $\mathrm{Ca}^{2+}$ influx into the cytosol and enhances GhMYB108 expression in cotton root cells. GhMYB108 was demonstrated as interacting with the calmodulin-like protein GhCML11 in a calcium-dependent manner; thus, GhCML11 and GhMYB108 silencing enhances cotton susceptibility to $V$. dahliae [81]. A stress-responsive HD-ZIP I transcription factor in cotton, GhHB12, negatively regulates the resistance of cotton plants by suppressing JA response genes [82]. CBP60g and SARD1 are two related plant-specific transcription factors involved in SA signalling. The secretory protein VdSCP41 in V. dahliae directly targets CBP60g to inhibit plant immunity, and mutations in Arabidopsis CBP60g and SARD1 compromise resistance to V. dahliae [83]. A homeodomain transcription factor gene (HDTF1) was isolated from cotton, and silencing HDTF1 was found to significantly enhance cotton plant resistance to $V$. dahliae and Botrytis cinerea, resulting in activation of JA-mediated signalling and JA accumulation [84]. Further, a basic helix-loop-helix (bHLH) transcription factor, GbbHLH171, interacts with and is phosphorylated by a defence-related receptor-like kinase in G. barbadense, namely, GbSOBIR1, in vitro and in vivo, and has a positive effect on cotton resistance to $V$. dahliae [85].

\section{Signal Transduction}

The ribosomal protein L18 (GaRPL18) gene from G.arboreum mediates plant resistance to $V$. dahliae via an SA-related signalling pathway. Silencing GaRPL18 impairs cotton plants resistance to V. dahliae, whereas GaRPL18 overexpression enhances Arabidopsis resistance to V. dahliae [86]. The phi-class glutathione (GSH) S-transferase gene (GaGSTF9) in Gossypium arboreum was found to be induced by $V$. dahliae via SA-related signalling pathway. GaGSTF9 silencing in cotton enhances its susceptibility. Conversely, the overexpression of GaGSTF9 increases Arabidopsis resistance to V. dahliae and the accumulation of endogenous SA and GST, indicating that GST might adjust ROS content via catalytic reduction of the tripeptide GSH, which in turn affects SA content [87].

Spermine (Spm) signalling is correlated with plant resistance to abiotic and biotic stresses. Two key rate-limiting enzymes in Spm biosynthesis are Spm synthase (GhSPMS) and S-adenosylmethionine decarboxylase (GhSAMDC), and GhSAMDC and GhSPMS silencing in cotton impairs plant resistance to $V$. dahliae infection. Enhanced resistance and the higher accumulation of Spm, SA, and leucine in transgenic $A$. thaliana overexpressing GhSAMDC suggest that GhSAMDC mediates Spm biosynthesis and contributes to plant resistance to $V$. dahliae via SA- and leucine-related signalling pathways [88]. The overexpression of cotton GhACL5 in Arabidopsis increases both plant height and T-Spm levels. Moreover, GhACL5 silencing in cotton results in a dwarf phenotype and also reduces resistance to $V$. dahliae. These results suggest that GhACL5 expression is related to in planta levels of T-Spm and contributes to stem elongation and defence responses to $V$. dahliae [89]. A polyamine oxidase gene 
(PAO), which can catalyse the conversion of Spm to spermidine (Spd), is induced early and strongly via plant hormone application and inoculation with $V$. dahliae. The constitutive expression of GhPAO in $A$. thaliana enhances resistance against $V$. dahliae and results in the accumulation of high levels of hydrogen peroxide, SA, and camalexin (a phytoalexin). These results suggest that GhPAO contributes to plant resistance to $V$. dahliae by activating Spm and camalexin signalling pathways [90].

Cotton cyclin-dependent kinase $\mathrm{E}$ (GhCDKE) is induced in cotton via V. dahliae infection and MeJA treatment. GhCDKE increases plant resistance to $V$. dahliae, which is mediated by the JA response pathway. GhCDKE silencing in cotton enhances susceptibility to Verticillium wilt pathogen, whereas GhCDKE overexpression in A. thaliana increases resistance to the pathogen [91]. GbWRKY1, a negative regulator of the JA-mediated defence pathway, contributes to plant resistance against $B$. cinerea and $V$. dahliae. During plant infection by $V$. dahliae, GbWRKY1 is also a key regulator that mediates the plant defence-to-development transition by activating JAZ1 expression [92]. GhCPK33 from G. hirsutum negatively regulates cotton resistance to $V$. dahliae by directly controlling JA biosynthesis. GhCPK33 silencing was shown to constitutively activate JA biosynthesis and JA mediated-defence responses and enhance resistance to $V$. dahliae infection [93]. GbSSI2 is an important regulator of the crosstalk between SA and JA signalling pathways. Moreover, the exogenous application of brassinolide can activate brassinosteroids and JA and enhance the resistance of cotton plants to V. dahliae [50].

Further, one study found that ET signalling in cotton roots infected with V. dahliae is significantly activated, which resulted in the high expression of ET biosynthesis and signal components [94]. The etr1-1 (ET receptor mutant) Arabidopsis strain shows enhanced resistance to $V$. dahliae, as well as enhanced activation and increased accumulation of CHI-1, CHI-2, GSTF12, GSTU16, Myb75, PR-1, PR-2, and PR-5 [95]. Ethylene-responsive factors (ERFs) commonly play an important role in pathogen defence responses. GbERFb, a new AP2/ERF transcription factor, can improve plant disease resistance [96]. GbERF1-like, ET response-related factor derived from G. barbadense, contributes to plant resistance against $V$. dahliae by positively regulating lignin synthesis. This resistance depends on the activation of GhHCT1 and AtPAL3 promoters by GbERF1-like proteins [97]. GbABR1 is an ERF subfamily B4 member and a new member of the AP2 family from G. barbadense. GbABR1-silenced plants show a higher disease index, indicating that this gene positively regulates resistance to Verticillium wilt [98].

Nucleotide-binding site leucine-rich repeat (NBS-LRR) proteins play a key role in plant defence against pathogens. A genome-wide association study indicated that CG02-containing TIR-NBS-LRR domains are the most likely candidate underlying cotton resistance to $V$. dahliae [99]. The island cotton NBS-LRR gene GbaNA1 can be induced by the pathogen $V$. dahliae and by the phytohormones ET, JA, and SA, contributing to island cotton resistance to V. dahliae isolate Vd991 [100]. The overexpression of GbaNA1 in A. thaliana enhances ROS content and the expression of genes related to the ethylene signalling pathway [101].

Serine/threonine-protein kinase (STK) is involved in responses to pathogen infection and oxidative stress via phosphorylation. The overexpression of G. barbadense GbSTK in Arabidopsis enhances resistance to $V$. dahliae and elevates PR-4, PR-5, and EREBP expression [102]. Moreover, the mitogen-activated protein kinase (MAPK) cascade plays key roles in plant defence against pathogen attack. MKK members in MAPK signalling cascades play dual roles in subtly regulating the resistance of cotton plants to Verticillium wilt; GhMKK4, GhMKK6, and GhMKK9 positively regulate, whereas GhMKK10 negatively regulates, cotton resistance [103]. As such, GhMKK2 and GhNDR1 silencing compromises the resistance of cotton plants to $V$. dahliae infection [104].

\section{Concluding Remarks}

Currently, numerous genes related to $V$. dahliae resistance have been identified in plants (Table 1). However, Verticillium wilt is still an enormous threat to agricultural production. Due to the presence of microsclerotia in $V$. dahliae, it can survive in the soil for many years, and it rapidly spreads; thus, it is difficult to control once infection occurs. Moreover, there is no fungicide available for plants, further 
limiting efficient control. Currently, the most effective control measures are genetic resistance. Therefore, it is necessary to further explore the genes related to $V$. dahliae resistance in plants. Resistance-related genes can be explored from various perspectives such as extracellular enzymes, the cell wall, PRRs, transcription factors, and SA/JA/ET-related signal transduction pathways. The further development of new technology such as host-induced gene silencing can aid in plant protection. At present, many genes remain unidentified, and there are few known genes related to resistance. Therefore, the technology available for genetic research is also extremely limited. In this paper, we summarised the genes related to $V$. dahliae resistance in plants on the basis of extracellular enzymes, cell walls, PRRs, transcription factors, and SA/JA/ET-related signal transduction pathways. This report provides a good theoretical resource for researchers and could aid in the discovery of additional genes related to resistance by providing a theoretical basis to further understand the molecular genetic mechanisms of plant resistance to $V$. dahliae. With the development of molecular biology technology and the application of multi-omics integrative analyses to the study plant disease resistance mechanisms, it is possible to study interactions between plants and Verticillium wilt, which will contribute to the discovery of plant disease resistance genes. At the same time, with the in-depth analysis of the molecular mechanisms underlying plant resistance to Verticillium wilt, it will be possible to obtain crops varieties that are resistant to Verticillium wilt through genetic engineering and breeding technology. 
Table 1. Genes related to plant resistance to V. dahlia and their regulatory mechanisms.

\begin{tabular}{|c|c|c|c|c|c|}
\hline Classification & Protein (Gene) Name & Annotation & Host & Resistance Mechanism & References \\
\hline \multirow{9}{*}{$\begin{array}{l}\text { Defence-related } \\
\text { proteins }\end{array}$} & PGIP & plant defence protein & $\mathrm{Ck}, \mathrm{Gh}$ & inhibit fungal polygalacturonase activity & [24] \\
\hline & $\mathrm{NaD1}$ & plant defensin & $\mathrm{Na}$ & antifungal activity & [26] \\
\hline & GbNRX1 & apoplastic thioredoxin protein & $\mathrm{Gb}$ & apoplastic immune response and scavenge ROS & [27] \\
\hline & GbHyPRP1 & proline-rich protein & $\mathrm{Gb}$ & thickening cell walls and ROS accumulation & [28] \\
\hline & AtNPR1 & non-expressor of $\operatorname{Pr} 1$ & At & upregulating expression of ICS1 and PR1a & [30] \\
\hline & GhMLP28 & defence-related major latex protein & St & enhance GhERF6 activity & [32] \\
\hline & GbTLP1 & thaumatin-like protein & $\mathrm{Gb}$ & secondary cell wall development & [34] \\
\hline & BTD-S & synthetic defensin derivative & Synthetic & antifungal activity & {$[35,36]$} \\
\hline & StoCYP77A2 & cytochrome P450 & $\mathrm{Nt}$ & synthesis of antimicrobial compounds & [37] \\
\hline \multirow{7}{*}{ Enzymes } & Chi28 & class IV chitinase subfamily & Gh, Gb & degrade the fungal cell wall & [42] \\
\hline & GhPMEI3 & pectin methylesterases & Gh & degrade the fungal cell wall & [43] \\
\hline & GhLAC15 & laccase & Gh & lignification of the cell wall & [45] \\
\hline & GbSBT1 & a subtilase gene & $\mathrm{Gb}$ & activating defence-related genes expressionn & [46] \\
\hline & GhECR & enoyl-CoA reductase & Gh & production of very long chain fatty acids & [47] \\
\hline & GbANS & anthocyanidin synthase & $\mathrm{Gb}$ & regulating biosynthesis of anthocyanins & [48] \\
\hline & GhPUB17 & U-box E3 ubiquitin ligase & Gh & negatively regulating immunity & [49] \\
\hline \multirow{8}{*}{$\begin{array}{l}\text { Receptor-like } \\
\text { proteins }\end{array}$} & GhDIR1 & putative dirigent protein & Gh & lionification of the cll woll & [38] \\
\hline & GhUMC1 & umecyanin-like protein & Gh & ignincation or the cell wall & [39] \\
\hline & Lyp1, Lyk7,LysMe3 & & $\mathrm{Gb}$ & recognize chitin, receptor-mediated & [53] \\
\hline & Gh-LYK1,Gh-LYK2 & lysin-motit receptor kinases & Gh & endocytosis-like signals and leucine zipper, & [54] \\
\hline & $V e 1$ and $V e 2$ & cell-surface glycoproteins & $\mathrm{Sl}$ & enhance the expression of the JA/ET signalling & {$[16,25]$} \\
\hline & GbSOBIR1 & $\begin{array}{l}\text { defence-related receptor-like } \\
\text { kinases }\end{array}$ & $\mathrm{Gb}$ & $\begin{array}{l}\text { pathway-related genes, increase the expressions of } \\
\text { defence-related genes }\end{array}$ & [85] \\
\hline & $\begin{array}{l}\text { Gbvdr3, Gbvdr6 } \\
\text { Gbve1, VvVe, StVe } \\
\text { StoVe1,SlVe1, GbRLK }\end{array}$ & Ve1 homologues & $\begin{array}{l}\mathrm{Gb}, \mathrm{Vv} \\
\mathrm{St}, \mathrm{Sl}\end{array}$ & & {$[17,64,68-74]$} \\
\hline & $\operatorname{miR} 482 e$ & miR482 superfamily & St & $\begin{array}{l}\text { target disease-resistance proteins with NBS and } \\
\text { LRR motifs }\end{array}$ & [79] \\
\hline \multirow{3}{*}{$\begin{array}{l}\text { Transcription } \\
\text { factors }\end{array}$} & GhHB12 & HD-ZIP I transcription factor & Gh & suppressing JA-response genes & [82] \\
\hline & GhMYB108 & plant MYB transcription factors & Gh & enhance defence signalling molecules & [81] \\
\hline & CBP60g and SARD1 & plant-specific transcription factors & At & regulating SA signalling & [83] \\
\hline
\end{tabular}


Table 1. Cont.

\begin{tabular}{|c|c|c|c|c|c|}
\hline Classification & Protein (Gene) Name & Annotation & Host & Resistance Mechanism & References \\
\hline \multirow{11}{*}{$\begin{array}{l}\text { Signal } \\
\text { transduction }\end{array}$} & GaRPL18 & ribosomal protein L18 & $\mathrm{Ga}$ & \multirow{2}{*}{$\begin{array}{l}\text { mediate resistance by SA-signalling } \\
\text { regulating ROS via catalytic reduction of } \\
\text { glutathione }\end{array}$} & [86] \\
\hline & GaGSTF9 & phi-class glutathione S-transferase & $\mathrm{Ga}$ & & {$[87]$} \\
\hline & GhSAMDC,GhSPMS & $\begin{array}{l}\text { S-adenosylmethionine } \\
\text { decarboxylase }\end{array}$ & Gh & regulating Spm biosynthesis by SA-signalling & [88] \\
\hline & GhPAO & polyamine oxidase & Gh & \multirow{8}{*}{$\begin{array}{l}\text { regulating Spm and camalexin signalling } \\
\text { enhance plant resistance by JA pathway } \\
\text { activation of JA-mediated signalling } \\
\text { activating JAZ1 expression } \\
\text { activating JA-mediated signalling } \\
\text { regulating ROS and ET signalling pathway } \\
\text { activation and increased accumulation of defence } \\
\text { proteins } \\
\text { positive regulator in lignin synthesis }\end{array}$} & [90] \\
\hline & GhCDKE & cyclin-dependent kinase & Gh & & [91] \\
\hline & HDTF1 & homeodomain transcription factor & Gh & & [84] \\
\hline & GbWRKY1 & regulator mediating & $\mathrm{Gb}$ & & [92] \\
\hline & GbSSI2,GbCAD1 & regulating signal pathways & $\mathrm{Gb}$ & & [50] \\
\hline & GbaNA1 & NBS-LRR protein & $\mathrm{Gb}$ & & {$[100,101]$} \\
\hline & ETR1 & ET receptor & At & & {$[95]$} \\
\hline & GbERF1-like & ET response-related factor & $\mathrm{Gb}$ & & [97] \\
\hline
\end{tabular}

Notes: At, Arabidopsis thaliana; Ck, Cynanchum komarovii; ET, ethylene; Ga, Gossypium arboreum; Gb, Gossypium barbadense; Gh, Gossypium hirsutum; ICS, isochorismate synthase; JA, jasmonic acid; LncRNAs, long noncoding RNAs; Na, Nicotiana alata; Nt, Nicotiana tabacum; Pr, pathogenesis-related protein; ROS, reactive oxygen species; SA, salicylic acid; Spm, spermine; Sl, Solanum lycopersicum; $\mathrm{St}$, Solanum torvum; T, threonine; $\mathrm{Vv}$, Vitis vinifera. 
Funding: This research was funded by [the Basic Research and Frontier Exploration Foundation of Chongqing] grant number [cstc2018jcyjAX0707, cstc2017jcyjA0573] and [the National Natural Science Foundation of China] grant number [31701734].

Conflicts of Interest: The authors declare that they have no conflict of interest.

\section{References}

1. Klosterman, S.J.; Atallah, Z.K.; Vallad, G.E.; Subbarao, K.V. Diversity, pathogenicity; and management of Verticillium Species. Annu. Rev. Phytopathol. 2009, 47, 39-62. [CrossRef]

2. Fradin, E.F.; Thomma, B.P. Physiology and molecular aspects of Verticillium wilt diseases caused by V. dahliae and V. albo-atrum. Mol. Plant Pathol. 2006, 7, 71-86. [CrossRef] [PubMed]

3. Wang, X.K.; Wang, C.Y.; Xie, C.J.; Yang, X.Y. Advances in molecular mechanisms of Verticillium pathogenicity and plant resistance to Verticillium wilt. J. Henan. Agr. Sci. 2014, 43, 1-6.

4. Zhang, J.; Fang, H.; Zhou, H.; Sanogo, S.; Ma, Z. Genetics; breeding; and marker-assisted selection for Verticillium wilt resistance in cotton. Crop Sci. 2014, 54, 1289-1303. [CrossRef]

5. Prieto, P.; Navarroraya, C.; Valverdecorredor, A.; Amyotte, S.G.; Dobinson, K.F.; Mercadoblanco, J.; Segura, A.; Preston, G.; Wit, P.D. Colonization process of olive tissues by Verticillium dahliae and its in planta interaction with the biocontrol root endophyte Pseudomonas fluorescens PICF7. Microb. Biotechnol. 2010, 2, 499-511. [CrossRef] [PubMed]

6. Zhao, P.; Zhao, Y.L.; Jin, Y.; Zhang, T.; Guo, H.S. Colonization process of Arabidopsis thaliana roots by a green fluorescent protein-tagged isolate of Verticillium dahliae. Protein Cell 2014, 5, 94-98.

7. Shaban, M.; Miao, Y.; Ullah, A.; Khan, A.H.; Ahmed, M.M.; Tabassum, M.A.; Zhu, L. Physiological and molecular mechanism of defense in cotton against Verticillium dahliae. Plant Physiol. Biochem. 2018, 125, 193-204. [CrossRef]

8. Temple, S.H.; DeVay, J.; Forrester, L.L. Temperature effects upon development and pathogenicity of defoliating and nondefoliating pathotypes of Verticillium dahliae in leaves of cotton plants. Phytopathology 1973, 63, 953-958. [CrossRef]

9. Daayf, F. Verticillium wilts in crop plants: Pathogen invasion and host defence responses. Can. J. Plant Pathol. 2015, 37, 8-20. [CrossRef]

10. Talboys, P.W. Association of tylosis and hyperplasia of the xylem with vascular invasion of the hop by Verticillium albo-atrum. Trans. Brit. Mycol. Soc. 1958, 41, 249-260. [CrossRef]

11. Meyer, R.; Slater, V.; Dubery, I.A. A phytotoxic protein-lipopolysaccharide complex produced by Verticillium dahliae. Phytochemistry 1994, 35, 1449-1453. [CrossRef]

12. Porter, C.; Green, R. Production of exotoxin in the genus Verticillium. Phytopathology 1952, 42, 472.

13. Luo, X.; Xie, C.; Dong, J.; Yang, X.; Sui, A. Interactions between Verticillium dahliae and its host: Vegetative growth, pathogenicity, plant immunity. Appl. Microbiol. Biotechnol. 2014, 98, 6921-6932. [CrossRef] [PubMed]

14. Belien, T.; Van, C.S.J.; Volckaert, G. Microbial endoxylanases, effective weapons to breach the plant cell-wall barrier or, rather, triggers of plant defense systems? Mol. Plant-Microbe Interact. 2006, 19, 1072-1081. [CrossRef] [PubMed]

15. Jones, J.D.; Dangl, J.L. The plant immune system. Nature 2006, 444, 323-329. [CrossRef] [PubMed]

16. Fradin, E.F.; Zhang, Z.; Rovenich, H.; Song, Y.; Liebrand, T.W.; Masini, L.; van den Berg, G.C.; Joosten, M.H.; Thomma, B.P. Functional analysis of the tomato immune receptor Ve1 through domain swaps with its non-functional homolog Ve2. PLoS ONE 2014, 9, e88208. [CrossRef]

17. Zhao, J.; Zhang, Z.; Gao, Y.; Zhou, L.; Fang, L.; Chen, X.; Ning, Z.; Chen, T.; Guo, W.; Zhang, T. Overexpression of GbRLK, a putative receptor-like kinase gene, improved cotton tolerance to Verticillium wilt. Sci. Rep. 2015, 5, 15048.

18. Bu, B.; Qiu, D.; Zeng, H.; Guo, L.; Yuan, J.; Yang, X. A fungal protein elicitor PevD1 induces Verticillium wilt resistance in cotton. Plant Cell Rep. 2014, 33, 461-470. [CrossRef]

19. Liang, Y.; Cui, S.; Tang, X.; Zhang, Y.; Qiu, D.; Zeng, H.; Guo, L.; Yuan, J.; Yang, X. An asparagine-rich protein Nbnrp1 modulate Verticillium dahliae protein PevD1-induced cell death and disease resistance in Nicotiana benthamiana. Front. Plant Sci. 2018, 9, 303. [CrossRef]

20. Liu, M.; Khan, N.U.; Wang, N.; Yang, X.; Qiu, D. The protein elicitor PevD1 enhances resistance to pathogens and promotes growth in Arabidopsis. Int. J. Biol. Sci. 2016, 12, 931-943. [CrossRef] 
21. Zhang, Y.; Gao, Y.; Liang, Y.; Dong, Y.; Yang, X.; Qiu, D. Verticillium dahliae PevD1, an Alt a 1-like protein, targets cotton PR5-like protein and promotes fungal infection. J. Exp. Bot. 2019, 70, 613-626. [CrossRef] [PubMed]

22. Zhou, R.; Zhu, T.; Han, L.; Liu, M.; Xu, M.; Liu, Y.; Han, D.; Qiu, D.; Gong, Q.; Liu, X. The asparagine-rich protein NRP interacts with the Verticillium effector PevD1 and regulates the subcellular localization of cryptochrome 2. J. Exp. Bot. 2017, 68, 3427-3440. [CrossRef] [PubMed]

23. Liu, N.; Ma, X.; Yun, S.; Zhang, X.; Li, F.; Hou, Y. Necrotizing activity of Verticillium dahliae and Fusarium oxysporum f. sp. vasinfectum endopolygalacturonases in cotton. Plant Dis. 2017, 101, 1128-1138. [PubMed]

24. Liu, N.; Zhang, X.; Sun, Y.; Wang, P.; Li, X.; Pei, Y.; Li, F.; Hou, Y. Molecular evidence for the involvement of a polygalacturonase-inhibiting protein, GhPGIP1, in enhanced resistance to Verticillium and Fusarium wilts in cotton. Sci. Rep. 2017, 7, 39840. [CrossRef] [PubMed]

25. Nazar, R.N.; Xu, X.; Kurosky, A.; Robb, J. Antagonistic function of the Ve R-genes in tomato. Plant Mol. Biol. 2018, 98, 67-79. [CrossRef] [PubMed]

26. Gaspar, Y.M.; McKenna, J.A.; McGinness, B.S.; Hinch, J.; Poon, S.; Connelly, A.A.; Anderson, M.A.; Heath, R.L. Field resistance to Fusarium oxysporum and Verticillium dahliae in transgenic cotton expressing the plant defensin NaD1. J. Exp. Bot. 2014, 65, 1541-1550. [CrossRef]

27. Li, Y.B.; Han, L.B.; Wang, H.Y.; Zhang, J.; Sun, S.T.; Feng, D.Q.; Yang, C.L.; Sun, Y.D.; Zhong, N.Q.; Xia, G.X. The thioredoxin GbNRX1 plays a crucial role in homeostasis of apoplastic reactive oxygen species in response to Verticillium dahliae infection in cotton. Plant Physiol. 2016, 170, 2392-2406. [CrossRef]

28. Yang, J.; Zhang, Y.; Wang, X.; Wang, W.; Li, Z.; Wu, J.; Wang, G.; Wu, L.; Zhang, G.; Ma, Z. HyPRP1 performs a role in negatively regulating cotton resistance to Verticillium dahliae via the thickening of cell walls and ROS accumulation. BMC Plant Boil. 2018, 18, 339.

29. Pajerowska-Mukhtar, K.M.; Emerine, D.K.; Mukhtar, M.S. Tell me more: Roles of NPRs in plant immunity. Trends Plant Sci. 2013, 8, 402-411. [CrossRef]

30. Parkhi, V.; Kumar, V.; Campbell, L.A.M.; Bell, A.A.; Rathore, K.S. Expression of Arabidopsis NPR1 in transgenic cotton confers resistance to non-defoliating isolates of Verticillium dahliae but not the defoliating isolates. J. Phytopathol. 2010, 158, 822-825. [CrossRef]

31. Jue, D.; Liu, Y.; Shi, C.; Min, C.; Yang, Q. Cloning and characterization of a Solanum torvum NPR1 gene involved in regulating plant resistance to Verticillium dahliae. Acta Physiol. Plant. 2014, 36, 2999-3011.

32. Yang, C.L.; Liang, S.; Wang, H.Y.; Han, L.B.; Wang, F.X.; Cheng, H.Q.; Wu, X.M.; Qu, Z.L.; Wu, J.H.; Xia, G.X. Cotton major latex protein 28 functions as a positive regulator of the ethylene responsive factor 6 in defense against Verticillium dahliae. Mol. Plant. 2015, 8, 399-411. [CrossRef] [PubMed]

33. Fu, X.; Li, C.; Zhou, X.; Liu, S.; Wu, F. Physiological response and sulfur metabolism of the V. dahliae-infected tomato plants in tomato/potato onion companion cropping. Sci. Rep. 2016, 6, 36445. [CrossRef] [PubMed]

34. Munis, M.F.; Tu, L.; Deng, F.; Tan, J.; Xu, L.; Xu, S.; Long, L.; Zhang, X. A thaumatin-like protein gene involved in cotton fiber secondary cell wall development enhances resistance against Verticillium dahliae and other stresses in transgenic tobacco. Biochem. Biophys. Res. Commun. 2010, 393, 38-44. [CrossRef]

35. Li, F.; Shen, H.; Wang, M.; Fan, K.; Bibi, N.; Ni, M.; Yuan, S.; Wang, X. A synthetic antimicrobial peptide BTD-S expressed in Arabidopsis thaliana confers enhanced resistance to Verticillium dahliae. Mol. Genet. Genom. 2016, 291, 1647-1661. [CrossRef]

36. Ni, M.; Zhao, Y.; Bibi, N.; Shao, M.; Yuan, S.; Fan, K.; Zhang, G.; Li, F.; Wang, X. A non-cyclic baboon $\theta$-defensin derivative exhibiting antimicrobial activity against the phytopathogen Verticillium dahliae. Appl. Microbiol. Bio. 2013, 97, 2043-2052. [CrossRef]

37. Liu, Y.; Shi, C.; Mu, X.; Chao, L.; Ke, S.; Zhu, W.; Yang, Q. Cloning and expression of a wild eggplant cytochrome P450 gene, StoCYP77A2, involved in plant resistance to Verticillium dahliae. Plant Biotech. Rep. 2015, 9, 167-177.

38. Shi, H.; Liu, Z.; Zhu, L.; Zhang, C.; Chen, Y.; Zhou, Y.; Li, F.; Li, X. Overexpression of cotton (Gossypium hirsutum) dirigent1 gene enhances lignification that blocks the spread of Verticillium dahliae. Acta Biochim. Biophys. Sin. 2012, 44, 555-564. [CrossRef]

39. Zhu, W.; Gao, E.; Shaban, M.; Wang, Y.; Wang, H.; Nie, X.; Zhu, L. GhUMC1, a blue copper-binding protein; regulates lignin synthesis and cotton immune response. Biochem. Bioph. Res. Commun. 2018, 504, 75-81. [CrossRef] 
40. Xu, J.; Xu, X.; Tian, L.; Wang, G.; Zhang, X.; Wang, X.; Guo, W. Discovery and identification of candidate genes from the chitinase gene family for Verticillium dahliae resistance in cotton. Sci. Rep. 2016, 6, 29022. [CrossRef]

41. Cheng, X.X.; Zhao, L.H.; Klosterman, S.J.; Feng, H.J.; Feng, Z.L.; Feng, W.; Shi, Y.Q.; Li, Z.F.; Zhu, H.Q. The endochitinase VDECH from Verticillium dahliae inhibits spore germination and activates plant defense responses. Plant Sci. 2017, 259, 12. [CrossRef]

42. Han, L.B.; Li, Y.B.; Wang, F.X.; Wang, W.Y.; Liu, J.; Wu, J.H.; Zhong, N.Q.; Wu, S.J.; Jiao, G.L.; Wang, H.Y.; et al. The cotton apoplastic protein CRR1 stabilizes chitinase 28 to facilitate defense against the fungal pathogen Verticillium dahliae. Plant Cell 2019, 31, 520-536. [CrossRef] [PubMed]

43. Liu, N.; Sun, Y.; Pei, Y.; Zhang, X.; Wang, P.; Li, X.; Li, F.; Hou, Y. A pectin methylesterase inhibitor enhances resistance to Verticillium wilt. Plant Physiol. 2018, 176, 2202-2220. [CrossRef] [PubMed]

44. Xu, L.; Zhu, L.; Tu, L.; Liu, L.; Yuan, D.; Jin, L.; Long, L.; Zhang, X. Lignin metabolism has a central role in the resistance of cotton to the wilt fungus Verticillium dahliae as revealed by RNA-Seq-dependent transcriptional analysis and histochemistry. J. Exp. Bot. 2011, 62, 5607-5621. [CrossRef]

45. Zhang, Y.; Wu, L.; Chen, B.; Zhao, J.; Cui, J.; Li, Z.; Yang, J.; Wu, L.; Zhang, G.; Ma, Z. The cotton laccase gene GHLAC15 enhances Verticillium wilt via an increase in defence-induced lignification and lignin components in the cell walls of plants. Mol. Plant Pathol. 2018, 20, 309-322. [CrossRef]

46. Duan, X.; Zhang, Z.; Wang, J.; Zuo, K. Characterization of a novel cotton subtilase gene GbSBT1 in response to extracellular stimulations and its role in Verticillium resistance. PLoS ONE 2016, 11, e0153988. [CrossRef]

47. Mustafa, R.; Hamza, M.; Kamal, H.; Mansoor, S.; Scheffler, J.; Amin, I. tobacco rattle virus-based silencing of enoyl-CoA reductase gene and its role in resistance against cotton wilt disease. Mol. Biotechnol. 2017, 59, 241-250. [CrossRef]

48. Long, L.; Zhao, J.R.; Xu, F.C.; Yang, W.W.; Liao, P.; Gao, Y.; Gao, W.; Song, C.P. Silencing of GbANS reduces cotton resistance to Verticillium dahliae through decreased ROS scavenging during the pathogen invasion process. Plant Cell Tiss. Org. 2018, 135, 213-221. [CrossRef]

49. Qin, T.; Liu, S.; Zhang, Z.; Sun, L.; He, X.; Lindsey, K.; Zhu, L.; Zhang, X. GhCyP3 improves the resistance of cotton to Verticillium dahliae by inhibiting the E3 ubiquitin ligase activity of GhPUB17. Plant Mol. Biol. 2019, 99, 379-393. [CrossRef]

50. Gao, W.; Long, L.; Zhu, L.F.; Xu, L.; Gao, W.H.; Sun, L.Q.; Liu, L.L.; Zhang, X.L. Proteomic and virus-induced gene silencing (VIGS) analyses reveal that gossypol, brassinosteroids, and jasmonic acid contribute to the resistance of cotton to Verticillium dahliae. Mol. Cell Proteomics 2013, 12, 3690-3703. [CrossRef]

51. Tanaka, K.; Nguyen, C.T.; Liang, Y.; Cao, Y.; Stacey, G. Role of LysM receptors in chitin-triggered plant innate immunity. Plant Signal Behav. 2013, 8, e22598. [CrossRef] [PubMed]

52. Wan, J.; Tanaka, K.; Zhang, X.C.; Son, G.H.; Brechenmacher, L.; Nguyen, T.H.; Stacey, G. LYK4, a lysin motif receptor-like kinase, is important for chitin signaling and plant innate immunity in Arabidopsis. Plant Physiol. 2012, 160, 396-406. [CrossRef] [PubMed]

53. Xu, J.; Wang, G.; Wang, J.; Li, Y.; Tian, L.; Wang, X.; Guo, W. The lysin motif-containing proteins, Lyp1, Lyk7 and LysMe3, play important roles in chitin perception and defense against Verticillium dahliae in cotton. BMC Plant Biol. 2017, 17, 148. [CrossRef] [PubMed]

54. Gu, Z.; Liu, T.; Ding, B.; Li, F.; Wang, Q.; Qian, S.; Ye, F.; Chen, T.; Yang, Y.; Wang, J.; et al. Two Lysin-motif receptor kinases; Gh-LYK1 and Gh-LYK2; contribute to resistance against Verticillium wilt in upland cotton. Front. Plant Sci. 2017, 8, 2133. [CrossRef]

55. Nazar, R.N.; Castroverde, C.D.M.; Xu, X.; Kurosky, A.; Robb, J. Wounding induces tomato Ve1 R-gene expression. Planta 2019, 249, 1779-1797. [CrossRef]

56. Kawchuk, L.M.; Hachey, J.; Lynch, D.R.; Kulcsar, F.; van Rooijen, G.; Waterer, D.R.; Robertson, A.; Kokko, E.; Byers, R.; Howard, R.J.; et al. Tomato Ve disease resistance genes encode cell surface-like receptors. Proc. Natl. Acad. Sci. USA 2001, 98, 6511-6515. [CrossRef]

57. Castroverde, C.D.; Xu, X.; Blaya, F.J.; Nazar, R.N.; Robb, J. Epistatic influence in tomato Ve1-mediated resistance. Plant Biol. 2017, 19, 843-847. [CrossRef]

58. De Jonge, R.; van Esse, H.P.; Maruthachalam, K.; Bolton, M.D.; Santhanam, P.; Saber, M.K.; Zhang, Z.; Usami, T.; Lievens, B.; Subbarao, K.V.; et al. Tomato immune receptor Ve1 recognizes effector of multiple fungal pathogens uncovered by genome and RNA sequencing. Proc. Natl. Acad. Sci. USA 2012, 109, 5110-5115. [CrossRef] 
59. Castroverde, C.D.; Xu, X.; Nazar, R.N.; Robb, J. Biotic factors that induce the tomato Ve1 R-gene. Plant Sci. 2017, 265, 61-69. [CrossRef]

60. Gayoso, C.; Pomar, F.; Novo-Uzal, E.; Merino, F.; de Ilarduya, O.M. The Ve-mediated resistance response of the tomato to Verticillium dahliae involves $\mathrm{H}_{2} \mathrm{O}_{2}$, peroxidase and lignins and drives PAL gene expression. BMC Plant Biol. 2010, 10, 232. [CrossRef]

61. Fradin, E.F.; Abd-El-Haliem, A.; Masini, L.; van den Berg, G.C.; Joosten, M.H.; Thomma, B.P. Interfamily transfer of tomato Ve1 mediates Verticillium resistance in Arabidopsis. Plant Physiol. 2011, 156, 2255-2265. [CrossRef] [PubMed]

62. Fradin, E.F.; Zhang, Z.; Juarez-Ayala, J.C.; Castroverde, C.D.; Nazar, R.N.; Robb, J.; Liu, C.M.; Thomma, B.P. Genetic dissection of Verticillium wilt resistance mediated by tomato Ve1. Plant Physiol. 2009, 150, 320-332. [CrossRef] [PubMed]

63. Song, Y.; Liu, L.; Wang, Y.; Valkenburg, D.J.; Zhang, X.; Zhu, L.; Thomma, B. Transfer of tomato immune receptor Ve1 confers Ave1-dependent Verticillium resistance in tobacco and cotton. Plant Biotechnol. J. 2018, 16, 638-648. [CrossRef] [PubMed]

64. Zhang, Z.; Fradin, E.; de Jonge, R.; van Esse, H.P.; Smit, P.; Liu, C.M.; Thomma, B.P. Optimized agroinfiltration and virus-induced gene silencing to study Ve1-mediated Verticillium resistance in tobacco. Mol. Plant Microbe. Interact. 2013, 26, 182-190. [CrossRef]

65. Zhang, Z.; van Esse, H.P.; van Damme, M.; Fradin, E.F.; Liu, C.M.; Thomma, B.P. Ve1-mediated resistance against Verticillium does not involve a hypersensitive response in Arabidopsis. Mol. Plant Pathol. 2013, 14, 719-727. [CrossRef]

66. Song, Y.; Zhang, Z.; Seidl, M.F.; Majer, A.; Jakse, J.; Javornik, B.; Thomma, B.P. Broad taxonomic characterization of Verticillium wilt resistance genes reveals an ancient origin of the tomato Ve1 immune receptor. Mol. Plant Pathol. 2017, 18, 195-209. [CrossRef]

67. Zhang, B.; Yang, Y.; Chen, T.; Yu, W.; Liu, T.; Li, H.; Fan, X.; Ren, Y.; Shen, D.; Liu, L. Island cotton Gbve1 gene encoding a receptor-like protein confers resistance to both defoliating and non-defoliating isolates of Verticillium dahliae. PLoS ONE 2012, 7, e51091. [CrossRef]

68. Yang, Y.; Chen, T.; Ling, X.; Ma, Z. Gbvdr6, a gene encoding a receptor-like protein of cotton (Gossypium barbadense), confers resistance to Verticillium wilt in Arabidopsis and upland cotton. Front. Plant Sci. 2017, 8, 2272. [CrossRef]

69. Zhang, B.J.; Zhang, H.P.; Chen, Q.Z.; Tang, N.; Wang, L.K.; Wang, R.F.; Zhang, B.L. Molecular cloning and analysis of a receptor-like promoter of Gbvdr3 gene in sea island cotton. Genet. Mol. Res. 2016, 15, gmr.15028636. [CrossRef]

70. Chen, T.; Kan, J.; Yang, Y.; Ling, X.; Chang, Y.; Zhang, B. A Ve homologous gene from Gossypium barbadense, Gbvdr3, enhances the defense response against Verticillium dahliae. Plant Physiol. Biochem. 2006, 98, 101-111. [CrossRef]

71. Tang, J.; Lin, J.; Yang, Y.; Chen, T.; Ling, X.; Zhang, B.; Chang, Y. Ectopic expression of a Ve homolog VvVe gene from Vitis vinifera enhances defense response to Verticillium dahliae infection in tobacco. Gene 2016, 576, 492-498. [CrossRef] [PubMed]

72. Liu, S.; Zhu, Y.; Xie, C.; Jue, D.; Hong, Y.; Chen, M.; Hubdar, A.K.; Yang, Q. Transgenic potato plants expressing StoVe1 exhibit enhanced resistance to Verticillium dahliae. Plant Mol. Biol. Rep. 2012, 30, 1032-1039. [CrossRef]

73. Chai, Y.; Zhao, L.; Liao, Z.; Sun, X.; Zuo, K.; Zhang, L.; Wang, S.; Tang, K. Molecular cloning of a potential Verticillium dahliae resistance gene SlVe1 with multi-site polyadenylation from Solanum licopersicoides. DNA Seq. 2003, 14, 375-384. [CrossRef] [PubMed]

74. Fei, J.; Chai, Y.; Wang, J.; Lin, J.; Sun, X.; Sun, C.; Zuo, K.; Tang, K. cDNA cloning and characterization of the Ve homologue gene StVe from Solanum torvum Swartz. DNA Seq. 2004, 15, 88-95. [CrossRef]

75. Jones-Rhoades, M.W.; Bartel, D.P. Computational identification of plant microRNAs and their targets; including a stress-induced miRNA. Mol. Cell 2004, 14, 787-799. [CrossRef]

76. Ellendorff, U.; Fradin, E.F.; Thomma, B.P.; De Jonge, R. RNA silencing is required for Arabidopsis defence against Verticillium wilt disease. J. Exp. Bot. 2008, 60, 591-602. [CrossRef]

77. He, X.; Sun, Q.; Jiang, H.; Zhu, X.; Mo, J.; Long, L.; Xiang, L.; Xie, Y.; Shi, Y.; Yuan, Y. Identification of novel microRNAs in the Verticillium wilt-resistant upland cotton variety KV-1 by high-throughput sequencing. SpringerPlus 2014, 3, 564. [CrossRef] 
78. He, X.H.; Shi, M.; Sun, Q.; Cai, Y.F. Expression profile analysis and target gene prediction of three conserved MicroRNAs in resistant Gossypium hirsutum cv. KV-1 responding to Verticillium dahlia. In Advanced Materials Research; Trans Tech Publications: Zurich, Switzerland, 2014; pp. 441-445.

79. Yang, L.; Mu, X.; Liu, C.; Cai, J.; Shi, K.; Zhu, W.; Yang, Q. Overexpression of potato miR482e enhanced plant sensitivity to Verticillium dahliae infection. J. Integ. Plant. Boil. 2015, 57, 1078-1088. [CrossRef]

80. Zhang, L.; Wang, M.; Li, N.; Wang, H.; Qiu, P.; Pei, L.; Xu, Z.; Wang, T.; Gao, E.; Liu, J. Long noncoding RNA s involve in resistance to Verticillium dahliae; a fungal disease in cotton. Plant Biotechnol. J. 2018, 16, 1172-1185. [CrossRef]

81. Cheng, H.Q.; Han, L.B.; Yang, C.L.; Wu, X.M.; Zhong, N.Q.; Wu, J.H.; Wang, F.X.; Wang, H.Y.; Xia, G.X. The cotton MYB108 forms a positive feedback regulation loop with CML11 and participates in the defense response against Verticillium dahliae infection. J. Exp. Bot. 2016, 67, erw016. [CrossRef] [PubMed]

82. He, X.; Wang, T.; Zhu, W.; Wang, Y.; Zhu, L. GhHB12, a HD-ZIP I transcription factor, negatively regulates the cotton resistance to Verticillium dahliae. Int. J. Mol. Sci. 2018, 19, 3997. [CrossRef] [PubMed]

83. Qin, J.; Wang, K.; Sun, L.; Xing, H.; Wang, S.; Li, L.; Chen, S.; Guo, H.S.; Zhang, J. The plant-specific transcription factors CBP60g and SARD1 are targeted by a Verticillium secretory protein VdSCP41 to modulate immunity. eLife 2018, 7, e34902. [CrossRef]

84. Gao, W.; Long, L.; Xu, L.; Lindsey, K.; Zhang, X.; Zhu, L. Suppression of the homeobox gene HDTF1 enhances resistance to Verticillium dahliae and Botrytis cinerea in cotton. J. Integr. Plant Biol. 2016, 58, 503-513. [CrossRef]

85. Zhou, Y.; Sun, L.; Wassan, G.M.; He, X.; Shaban, M.; Zhang, L.; Zhu, L.; Zhang, X. GbSOBIR1 confers Verticillium wilt resistance by phosphorylating the transcriptional factor GbbHLH171 in Gossypium barbadense. Plant Biotechnol. J. 2019, 17, 152-163. [CrossRef]

86. Gong, Q.; Yang, Z.; Wang, X.; Butt, H.I.; Chen, E.; He, S.; Zhang, C.; Zhang, X.; Li, F. Salicylic acid-related cotton (Gossypium arboreum) ribosomal protein GaRPL18 contributes to resistance to Verticillium dahliae. BMC Plant Biol. 2017, 17, 59. [CrossRef] [PubMed]

87. Gong, Q.; Yang, Z.; Chen, E.; Sun, G.; He, S.; Butt, H.I.; Zhang, C.; Zhang, X.; Yang, Z.; Du, X.; et al. A Phi-class glutathione S-transferase gene for Verticillium wilt resistance in Gossypium arboreum identified in a genome-wide association study. Plant Cell Physiol. 2018, 59, 275-289. [CrossRef]

88. Mo, H.J.; Sun, Y.X.; Zhu, X.L.; Wang, X.F.; Zhang, Y.; Yang, J.; Yan, G.J.; Ma, Z.Y. Cotton S-adenosylmethionine decarboxylase-mediated spermine biosynthesis is required for salicylic acid- and leucine-correlated signaling in the defense response to Verticillium dahliae. Planta 2016, 243, 1023-1039. [CrossRef]

89. Mo, H.; Wang, X.; Zhang, Y.; Yang, J.; Ma, Z. Cotton ACAULIS5 is involved in stem elongation and the plant defense response to Verticillium dahliae through thermospermine alteration. Plant Cell Rep. 2015, 34, 1975-1985. [CrossRef]

90. Mo, H.; Wang, X.; Zhang, Y.; Zhang, G.; Zhang, J.; Ma, Z. Cotton polyamine oxidase is required for spermine and camalexin signalling in the defence response to Verticillium dahliae. Plant J. 2015, 83, 962-975. [CrossRef]

91. Li, X.; Pei, Y.; Sun, Y.; Liu, N.; Wang, P.; Liu, D.; Ge, X.; Li, F.; Hou, Y. A cotton cyclin-dependent kinase E confers resistance to Verticillium dahliae mediated by jasmonate-responsive pathway. Front. Plant Sci. 2018, 9, 642. [CrossRef] [PubMed]

92. Li, C.; He, X.; Luo, X.; Xu, L.; Liu, L.; Min, L.; Jin, L.; Zhu, L.; Zhang, X. Cotton WRKY1 mediates the plant defense-to-development transition during infection of cotton by Verticillium dahliae by activating JASMONATE ZIM-DOMAIN1 expression. Plant Physiol. 2014, 166, 2179-2194. [CrossRef] [PubMed]

93. Hu, Q.; Zhu, L.; Zhang, X.; Guan, Q.; Xiao, S.; Min, L.; Zhang, X. GhCPK33 negatively regulates defense against Verticillium dahliae by phosphorylating GhOPR3. Plant Physiol. 2018, 178, 876-889. [CrossRef] [PubMed]

94. Wang, F.X.; Ma, Y.P.; Yang, C.L.; Zhao, P.M.; Yao, Y.; Jian, G.L.; Luo, Y.M.; Xia, G.X. Proteomic analysis of the sea-island cotton roots infected by wilt pathogen Verticillium dahliae. Proteomics 2011, 11, 4296-4309. [CrossRef]

95. Pantelides, I.S.; Tjamos, S.E.; Paplomatas, E.J. Ethylene perception via ETR1 is required in Arabidopsis infection by Verticillium dahliae. Mol. Plant Pathol. 2010, 11, 191-202. [CrossRef]

96. Liu, J.; Wang, Y.; Zhao, G.; Zhao, J.; Du, H.; He, X.; Zhang, H. A novel Gossypium barbadense ERF transcription factor, GbERFb, regulation host response and resistance to Verticillium dahliae in tobacco. Physiol. Mol. Biol. Plant. 2017, 23, 1-10. [CrossRef] 
97. Guo, W.; Jin, L.; Miao, Y.; He, X.; Hu, Q.; Guo, K.; Zhu, L.; Zhang, X. An ethylene response-related factor; GbERF1-like; from Gossypium barbadense improves resistance to Verticillium dahliae via activating lignin synthesis. Plant Mol. Biol. 2016, 91, 305-318. [CrossRef]

98. Liu, Y.; Xin, L.; Lu, L.; Wang, W.; Quan, S.; Bo, L.; Wang, C.; Cheng, J.; Zhang, Y.; Xie, Y. GbABR1 is associated with Verticillium wilt resistance in cotton. Biologia. 2018, 73, 449-457. [CrossRef]

99. Li, T.; Ma, X.; Li, N.; Zhou, L.; Liu, Z.; Han, H.; Gui, Y.; Bao, Y.; Chen, J.; Dai, X. Genome-wide association study discovered candidate genes of Verticillium wilt resistance in upland cotton (Gossypium hirsutum L). Plant Biotechnol. J. 2017, 15, 1520-1532. [CrossRef]

100. Li, N.Y.; Ma, X.F.; Short, D.P.G.; Li, T.G.; Zhou, L.; Gui, Y.J.; Kong, Z.Q.; Zhang, D.D.; Zhang, W.Q.; Li, J.J.; et al. The island cotton NBS-LRR gene GbaNA1 confers resistance to the non-race 1 Verticillium dahliae isolate Vd991. Mol. Plant Pathol. 2018, 19, 1466-1479. [CrossRef]

101. Li, N.Y.; Zhou, L.; Zhang, D.D.; Klosterman, S.J.; Li, T.G.; Gui, Y.J.; Kong, Z.Q.; Ma, X.F.; Short, D.P.G.; Zhang, W.Q.; et al. Heterologous expression of the cotton NBS-LRR gene GbaNA1 enhances Verticillium wilt resistance in Arabidopsis. Front. Plant Sci. 2018, 9, 119. [CrossRef] [PubMed]

102. Zhang, Y.; Wang, X.; Li, Y.; Wu, L.; Zhou, H.; Zhang, G.; Ma, Z. Ectopic expression of a novel Ser/Thr protein kinase from cotton (Gossypium barbadense), enhances resistance to Verticillium dahliae infection and oxidative stress in Arabidopsis. Plant Cell Rep. 2013, 32, 1703-1713. [CrossRef] [PubMed]

103. Meng, J.; Gao, H.; Zhai, W.; Shi, J.; Zhang, M.; Zhang, W.; Jian, G.; Zhang, M.; Qi, F. Subtle regulation of cotton resistance to Verticillium wilt mediated by MAPKK family members. Plant Sci. 2018, 272, 235-242. [CrossRef] [PubMed]

104. Gao, X.; Wheeler, T.; Li, Z.; Kenerley, C.M.; He, P.; Shan, L. Silencing GhNDR1 and GhMKK2 compromises cotton resistance to Verticillium wilt. Plant J. 2011, 66, 293-305. [CrossRef] [PubMed]

(C) 2020 by the authors. Licensee MDPI, Basel, Switzerland. This article is an open access article distributed under the terms and conditions of the Creative Commons Attribution (CC BY) license (http://creativecommons.org/licenses/by/4.0/). 